\title{
PERBEDAAN KADAR TRIGLISERIDA SERUM TIKUS SRAGUE DAWLEY PADA PEMBERIAN KOPI ROBUSTA FILTER DAN TANPA FILTER
}

\author{
Anggray Duvita Wahyani, Apoina Kartini") \\ Program Studi Ilmu Gizi Fakultas Kedokteran Universitas Diponegoro \\ Jl.Dr.Sutomo No.14, Semarang, Telp (024) 8453708, Email : gizifk@undip.ac.id
}

\begin{abstract}
Background: Dyslipidemia is a disorder of lipid metabolism characterized by (increasing or decreasing) lipid fraction disorders in blood plasma, such as triglyceride. Coffee is known as a bad effect coming from cafestol which can elevate triglyceride level on blood, nevertheless, it has positive effect coming from cafein which can decrease triglyseride level on blood.

Method: true-experimental with pre-post randomized control groups design was conducted in this study. Subjects were 8 week-old and male Sprague Dawley rats which are given of filter and nonfilter robusta coffee's solution for 4 weeks. Serum-triglyceride levels are determined with GPO-PAP method. Normality data was examined by Shapiro Wilks. Data was analyzed with paired t-test and one way ANOVA.

Result: This study showed the averages of pre triglycerides level in coffee filter are 99,67 mg/dl and post triglycerides level are $94,78 \mathrm{mg} / \mathrm{dl}(\mathrm{p}=0,760)$. The averages of pre triglycerides level in unfilter coffee are 95,11 $\mathrm{mg} / \mathrm{dl}$ and post triglycerides level are $91,33 \mathrm{mg} / \mathrm{dl}(\mathrm{p}=0,693)$. Change averages of pre and post test in filtered coffee $-4,89 \mathrm{mg} / \mathrm{dl}$ and unfiltered coffee $-3,78 \mathrm{mg} / \mathrm{dl}(\mathrm{p}=0,329)$.

Conslusion: There were no differences in changes of triglyceride levels in the provision of robusta coffee filter and without filter
\end{abstract}

Keywords: filter coffee; nonfilter coffee; trygliseride level; sprague dawley rats

\begin{abstract}
ABSTRAK
Latar Belakang : Dislipidemia adalah kelainan metabolisme lipid yang ditandai dengan kelainan (peningkatan atau penurunan) fraksi lipid dalam plasma darah, salah satunya adalah trigliserida. Kopi diketahui mempunyai efek negatif dari kafestol yang dapat meningkatkan kadar trigliserida dalam darah. Namun demikian, kopi juga mempunyai efek positif dari kafein yang dapat menurunkan kadar trigliserida dalam darah.

Metode : Jenis penelitian ini adalah true-experimental dengan pre-post randomized control groups design. Subjek penelitian adalah tikus Sprague Dowley jantan berusia 8 minggu yang diberi larutan kopi robusta filter dan tanpa filter selama 4 minggu. Kadar trigliserida ditentukan dengan metode GPO-PAP. Normalitas data diuji dengan Shapiro Wilks. Data dianalisis dengan uji paired t-test dan one way anova.

Hasil : Hasil penelitian menunjukkan rerata kadar trigliserida awal pada pemberian kopi filter adalah 99,67 mg/dl dan kadar trigliserida akhir adalah 94,78 mg/dl ( $p=0,760)$. Rerata kadar trigliserida awal pada pemberian kopi tanpa filter adalah 95,11 mg/dl dan kadar trigliserida akhir adalah 91,33 $\mathrm{mg} / \mathrm{dl}$ ( $p=0,693)$. Rerata perubahan kadar trigliserida awal dan akhir pada pemberian kopi filter adalah -4,89 mg/dl dan pada kopi tanpa filter adalah $3,78 \mathrm{mg} / \mathrm{dl}(\mathrm{p}=0,329)$.
\end{abstract}

Simpulan : Tidak terdapat perbedaan perubahan kadar trigliserida pada pemberian kopi robusta filter dan tanpa filter.

Kata kunci : kopi filter; kopi tanpa filter; kadar trigliserida; tikus sprague dawley

\section{PENDAHULUAN}

Dislipidemia adalah kelainan metabolisme lipid yang ditandai dengan peningkatan atau penurunan fraksi lipid dalam plasma darah. ${ }^{1}$ Kelainan fraksi lipid tersebut dapat menimbulkan berbagai macam penyakit, seperti obesitas, stroke, dan penyakit jantung koroner. ${ }^{2}$ Data Survey Kesehatan Rumah Tangga tahun 2004 menyebutkan prevalensi dislipidemia di Indonesia mencapai $14 \% .^{3}$ Kelainan fraksi lipid yang utama misalnya kadar kolesterol yang tinggi, kadar HDL yang rendah, dan kadar trigliserida yang tinggi. ${ }^{1}$ Kadar trigliserida yang tinggi (hipertrigliserida) merupakan suatu keadaan trigliserida dalam darah meningkat melebihi batas normalnya yaitu lebih dari $150 \mathrm{ml} / \mathrm{dl}$. Membatasi makanan atau minuman yang tinggi lemak dan rendah serat merupakan salah satu cara untuk mengontrol hipertrigliserida. ${ }^{4}$

Kopi merupakan minuman yang banyak digemari oleh masyarakat dunia, termasuk juga di Indonesia. Indonesia menghasilkan kopi robusta lebih tinggi, yaitu sebesar 93\% dibandingkan kopi 
arabika. ${ }^{5}$ Berdasarkan informasi yang didapat dari ICO Coffee Statistics dan Asosiasi Eksportir Kopi Indonesia (AEKI), diketahui terdapat peningkatan konsumsi kopi dari tahun 2003 sampai 2005 sebanyak $25 \%$, dari konsumsi 120.000 ton menjadi 150.000 ton pada tahun 2005 . $^{6}$

Kopi mempunyai efek bipolar, yaitu mempunyai zat kafestol yang dapat meningkatkan kadar trigliserida darah dan zat kafein yang dapat menurunkan kadar trigliserida. ${ }^{7,8}$ Penelitian yang dilakukan oleh De Ross mengemukakan bahwa kopi mempunyai kandungan kafestol yang dapat meningkatkan kadar trigliserida dengan cara menghambat mekanisme beta oksidasi, mencegah pemecahan trigliserida menjadi energi sehingga kadar trigliserida dalam darah meningkat. ${ }^{7}$ Larutan kopi tanpa filter dapat meningkatkan kadar trigliserida lebih banyak daripada kopi filter. Hal ini dikarenakan kandungan kafestol 6-12 $\mathrm{mg} /$ cangkir, lebih banyak daripada kopi filter yaitu 0,2-0,6 mg/cangkir. ${ }^{8,9}$ Kadar kafestol yang berbeda diduga karena pada kopi filter senyawa kafestol dan kahweol telah tersaring pada kertas saring saat proses filtrasi. ${ }^{10}$

Hasil penelitian tentang pengaruh pemberian kopi terhadap kadar trigliserida masih kontroversi, sehingga mendorong peneliti untuk melakukan studi terhadap pengaruh pemberian larutan kopi serta perbedaan pengaruh kopi filter dan tanpa filter pada serum tikus sprague dawley.

\section{METODE PENELITIAN}

Pemeliharaan hewan percobaan dilakukan di Laboratorium Layanan Penelitian Pra Klinik dan Pengembangan Hewan Percobaan Jurusan Biologi, FMIPA Universitas Semarang. Penelitian ini merupakan rancangan true eksperiment dengan kelompok kontrol dan pembagian kelompok secara random. Variabel bebas pada penelitian ini adalah pemberian kopi robusta filter dan kopi robusta tanpa filter sedangkan variabel terikat dalam penelitian ini adalah kadar trigliserida.

Sampel yang digunakan adalah tikus jantan sprague dawley berjumlah 30 ekor dengan umur 8 minggu dan berat badan rata-rata 150-200 gram. Seluruh subjek diadaptasi terlebih dulu selama 7 hari dengan diberikan pakan standar BR2 serta air minum secara ad libitum. Setelah diadaptasi, tikus dikelompokkan menjadi 3 kelompok yang dilakukan secara random. Tiga kelompok terdiri dari satu kelompok sebagai kelompok kontrol dan dua kelompok sebagai kelompok perlakuan. Setelah dikelompokkan, kemudian dilakukan pengambilan darah tikus untuk mengetahui kadar trigliserida awal. Kelompok kontrol (P0) diberi pakan standar dan air minum secara ad libitum serta air minum secara per oral (sonde) sebanyak 4 kali sehari sedangkan pada kelompok perlakuan, diberi pakan standar dan air minum secara ad libitum serta larutan kopi filter pada kelompok P1 dan tanpa filter pada kelompok P2 secara per oral (sonde) sebanyak 4 kali sehari. Perlakuan diberikan selama 4 minggu, setelah itu dilakukan pengambilan darah tikus untuk mengetahui kadar trigliserida akhir setelah perlakuan.

Larutan kopi yang akan diberikan dibuat dengan cara kopi dilarutkan dalam air mendidih, didiamkan sebentar kemudian diberikan ke tikus secara sonde. Pada kelompok P1 (kopi filter) kopi yang telah dilarutkan tersebut disaring terlebih dahulu dengan menggunakan kertas filter, sedangkan pada kelompok P2 (kopi tanpa filter) kopi yang telah dilarutkan tidak dilakukan penyaringan. Dosis kopi yang diberikan adalah 0,18 gram. Pemberian dosis 0,18 gram berdasarkan kandungan kopi dalam secangkir kopi yang dikonsumsi oleh manusia yaitu 10 gram bubuk kopi kemudian dibandingkan dengan menggunakan tabel perbandingan luas permukaan tubuh hewan coba yaitu dosis tikus dengan berat 200 gram adalah 0,018 kali dosis manusia, maka dosis untuk hewan coba didapat dari perhitungan 10 gram $\times 0,018=0,18$ gram. $^{11}$ Berikut adalah bagan pembuatan larutan kopi untuk setiap kelompok perlakuan yang berjumlah 10 ekor tikus 


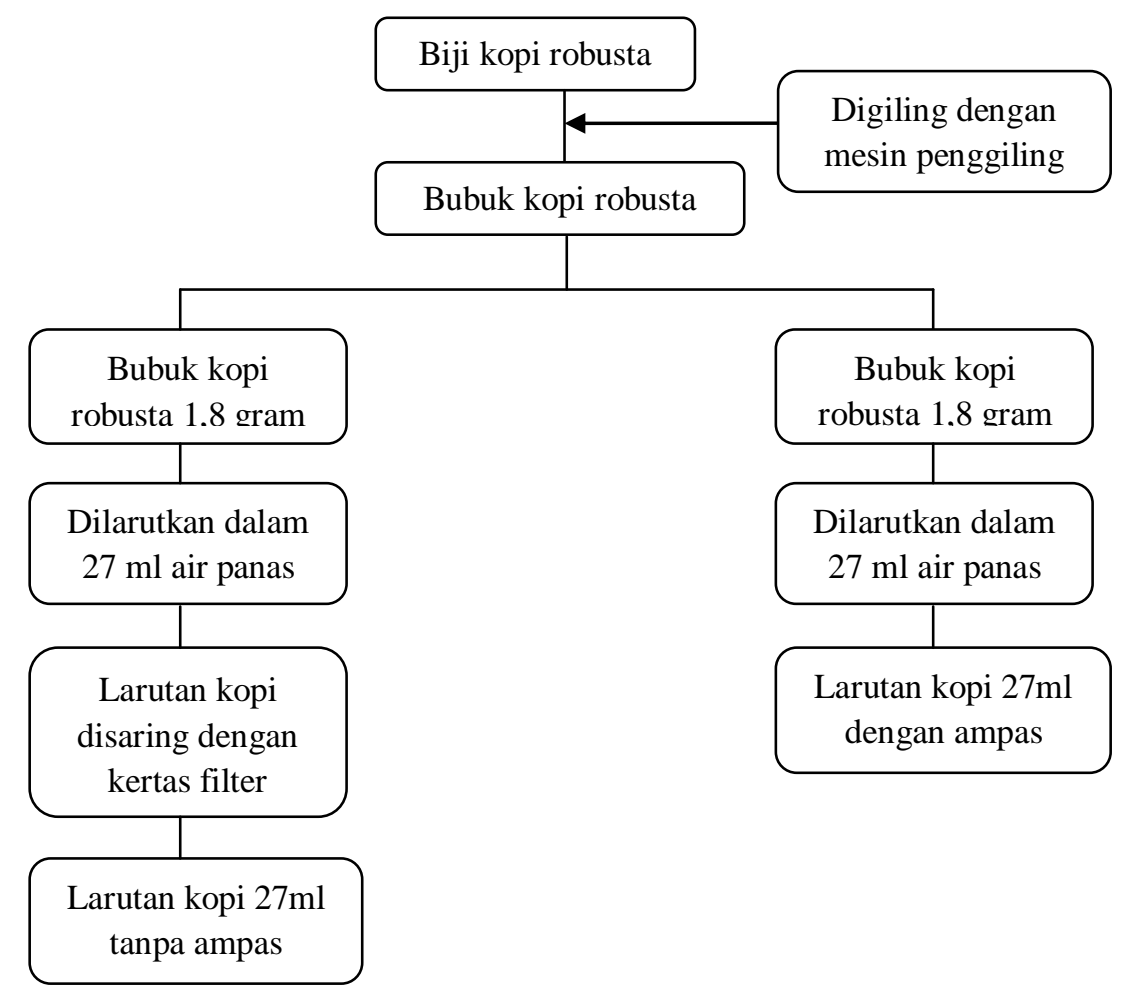

Pengambilan darah untuk pemeriksaan kadar trigliserida diambil sebanyak $2 \mathrm{ml}$ melalui sinus orbitalis. Kadar trigliserida ditentukan secara enzimatik dengan metoda GPO-PAP (glycerol phosphate oxydase - phenyl aminophyrazolon). ${ }^{12}$ Data yang diperoleh diolah menggunakan program komputer dan diuji secara deskriptif kemudian dilakukan uji normalitas menggunakan uji Shapiro-Wilk. Perbedaan trigliserida sebelum dan setelah perlakuan pada semua kelompok dilakukan uji paired t-test. Perbedaan dari ketiga kelompok perlakuan dianalisis menggunakan uji statistik parametrik One Way Anova. ${ }^{13}$

\section{HASIL PENELITIAN Kadar trigliserida sebelum dan sesudah perlakuan}

Tiga puluh tikus sprague Dawley berjenis kelamin jantan dipelihara dalam kandang individual. Selama perlakuan, terdapat dua ekor tikus mati pada kelompok kontrol (P0) dan kelompok kopi tanpa filter (P2) pada minggu pertama dan minggu ketiga sehingga digunakan dua puluh delapan ekor tikus sampai akhir perlakuan.

Pertumbuhan berat badan tikus dipantau dengan penimbangan yang dilakukan setiap tiga hari. Penimbangan berat badan dilakukan sebelum penyondean dengan tujuan untuk menghindari bias karena data berat badan sebenarnya atau berat badan karena penambahan volume cairan. Selain penimbangan berat badan, penimbangan sisa pakan dilakukan setiap hari untuk mengetahui asupan pakan setiap harinya. Hal tersebut dapat dilihat pada tabel 1 dan 2 .

Tabel 1. Perbedaan berat badan tikus sebelum dan sesudah perlakuan

\begin{tabular}{|c|c|c|c|c|}
\hline \multirow[t]{2}{*}{ Kelompok } & \multicolumn{2}{|c|}{ Berat Badan Tikus } & \multirow[t]{2}{*}{$\Delta$} & \multirow[t]{2}{*}{$p$} \\
\hline & Sebelum (gr) & Setelah (gr) & & \\
\hline P0 & $161,3 \pm 5,22$ & $200,2 \pm 13,09$ & 38,9 & $0,0001^{*}$ \\
\hline P1 & $185,7 \pm 14,09$ & $236,6 \pm 23,73$ & 46,7 & $0,0001^{*}$ \\
\hline P2 & $181,9 \pm 9,87$ & $238,8 \pm 23,48$ & 56,9 & $0,0001 *$ \\
\hline
\end{tabular}

Bedasarkan data yang ditunjukkan dari tabel 1, didapatkan hasil bahwa terdapat perbedaan yang bermakna $(p<0,05)$ antara berat badan sebelum dan berat badan setelah perlakuan pada semua kelompok. Selisih berat badan awal dan akhir paling tinggi terdapat pada kelompok P2, yaitu 56,9 gram dan paling rendah pada kelompok kontrol (P0) yaitu 38,9 gram. 
Tabel 2. Perbedaan asupan pakan tikus sebelum dan sesudah perlakuan

\begin{tabular}{|c|c|c|c|c|}
\hline \multirow[t]{2}{*}{ Kelompok } & \multicolumn{2}{|c|}{ Asupan Pakan } & \multirow[t]{2}{*}{$\Delta$} & \multirow[t]{2}{*}{$p$} \\
\hline & Sebelum (gr) & Selama (gr) & & \\
\hline $\mathrm{P} 0$ & $16,44 \pm 1,57$ & $12,91 \pm 1,94$ & $-3,53$ & $0,002 *$ \\
\hline P1 & $18,05 \pm 1,09$ & $15,22 \pm 1,80$ & $-2,83$ & $0,001 *$ \\
\hline P2 & $18,11 \pm 1,75$ & $15,46 \pm 1,64$ & $-2,65$ & $0,014 *$ \\
\hline
\end{tabular}

*memiliki perbedaan yang bermakna $(\mathrm{p}<0,05)$

Bedasarkan data yang ditunjukkan dari tabel 2, didapatkan hasil bahwa terdapat perbedaan yang bermakna $(\mathrm{p}<0,05)$ antara asupan pakan sebelum dan setelah perlakuan pada semua kelompok. Selisih asupan pakan sebelum dan sesudah paling tinggi terdapat pada kelompok P0, yaitu 3,53 gram dan paling rendah pada kelompok P2 yaitu 2,65 gram.

Pemeriksaan kadar trigliserida dilakukan pada sebelum dan setelah perlakuan. Berdasarkan hasil perlakuan selama 4 minggu terdapat gambaran rerata kadar trigliserida yang ditampilkan pada tabel 3 .

Tabel 3. Perbedaan kadar trigliserida sebelum dan setelah perlakuan

\begin{tabular}{|c|c|c|c|c|}
\hline \multirow[t]{2}{*}{ Kelompok } & \multicolumn{2}{|c|}{$\begin{array}{c}\text { Rerata Kadar Trigliserida } \\
(\mathbf{m g} / \mathrm{dl})\end{array}$} & \multirow[t]{2}{*}{$\Delta$} & \multirow[t]{2}{*}{$p$} \\
\hline & Sebelum & Setelah & & \\
\hline P0 & $126,67 \pm 39,41$ & $107,78 \pm 23,19$ & $-18,89$ & $0,0001^{*}$ \\
\hline P1 & $99,67 \pm 42,51$ & $94,78 \pm 27,81$ & $-4,89$ & 0,760 \\
\hline $\mathbf{P 2}$ & $95,11 \pm 26,22$ & $91,33 \pm 21,05$ & $-3,78$ & 0,693 \\
\hline
\end{tabular}

*memiliki perbedaan yang bermakna $(\mathrm{p}<0,05)$

Hasil analisis menunjukkan adanya penurunan kadar trigliserida pada semua kelompok setelah 4 minggu perlakuan. Penurunan kadar trigliserida secara bermakna terdapat pada kelompok kontrol (P0) dengan selisih kadar trigliserida awal dan akhir -18,89. Penurunan kadar trigliserida paling rendah terdapat pada kelompok perlakuan 2 (P2) dengan selisih kadar trigliserida awal dan akhir $-3,78$.

Untuk melihat perbedaan kadar trigliserida dan berat badan dari ketiga kelompok, dilakukan uji one way anova.

Tabel 4. Perbedaan perubahan asupan pakan, berat badan, dan kadar trigliserida pada tiga kelompok perlakuan.

\begin{tabular}{lcccc}
\hline \multicolumn{1}{c}{ Rerata } & P0 & P1 & P2 & $\boldsymbol{p}$ \\
& & & & \\
\hline$\Delta$ Asupan pakan & $-3,53 \mathrm{gr}$ & $-2,83 \mathrm{gr}$ & $-2,65 \mathrm{gr}$ & 0,680 \\
$\Delta$ Berat Badan & $38,9 \mathrm{gr}$ & $46,7 \mathrm{gr}$ & $56,9 \mathrm{gr}$ & 0,054 \\
$\Delta$ Kadar & $-18,89 \mathrm{mg} / \mathrm{dl}$ & $-4,89 \mathrm{mg} / \mathrm{dl}$ & $-3,78 \mathrm{mg} / \mathrm{dl}$ & 0,329 \\
Trigliserida & & & & \\
\hline
\end{tabular}

Hasil analisis uji one way anova kadar trigliserida, diketahui berat badan dan asupan pakan mempunyai nilai $p>0,05$. Hal ini menunjukkan bahwa tidak terdapat perbedaan pengaruh kadar trigliserida, berat badan, dan asupan pakan secara bermakna pada ketiga kelompok.

\section{PEMBAHASAN}

Hasil dari penelitian pemberian larutan kopi robusta filter dan tanpa filter diketahui terdapat penurunan kadar trigliserida pada ketiga kelompok perlakuan. Pada kelompok kontrol (P0) terjadi penurunan kadar trigliserida paling besar. Hal ini diduga karena asupan pakan pada kelompok kontrol (P0) paling rendah (12,91 gram) sehingga memicu pemecahan trigliserida. Penurunan asupan pakan ini dikarenakan pemberian air minum yang dilakukan secara sonde sebanyak 10,8 ml serta secara ad libitium diduga telah mencapai batas volume maksimal lambung 
tikus, yaitu $15 \mathrm{ml} .{ }^{14}$ Kondisi ini menyebabkan rasa kenyang pada tikus sehingga asupan pakan tikus berkurang. Penurunan asupan pakan menyebabkan penurunan cadangan glukosa untuk menghasilkan energi, sehingga terjadi proses glukoneogenesis. Pada kondisi ini, tubuh akan menggunakan cadangan lemak untuk menghasilkan energi dengan cara meningkatkan pemecahan trigliserida. $^{15}$

Pada kelompok perlakuan kopi filter dan tanpa filter juga terjadi penurunan kadar trigliserida. Penurunan trigliserida dikarenakan adanya zat kafein dalam kopi diduga dapat meningkatkan aktifitas beta oksidasi. ${ }^{16,17}$ Kafein adalah suatu senyawa kimia yang banyak terdapat pada minuman kopi, teh, softdrink dan cokelat. Kafein termasuk alkaloid dengan rumus kimia 1,3,7-trimethylxantine dan bersifat diuretik. ${ }^{18}$ Kafein dimetabolisme di hati oleh sistem enzim sitokrom P450 oksidase (lebih spesifik isozim 1A2) menjadi tiga dimethylxanthines metabolik yaitu paraxanthine yang berhubungan dengan lipolisis serta theobromin dan theophilin yang berhubungan dengan mekanisme diuresis kafein. ${ }^{16}$

Paraxanthine merupakan efek metabolik dari kafein paling besar (84\%). Paraxanthine menyebabkan peningkatan lipolisis melalui mekanisme beta oksidasi yang menyebabkan pemecahan trigliserida menjadi asam lemak bebas dan gliserol meningkat. ${ }^{16,17}$ Hal ini mengakibatkan kadar trigiserida dalam darah menurun. Kandungan kafein dalam 10 gram kopi sebanyak $150 \mathrm{mg} .{ }^{14}$ Pada penelitian yang dilakukan oleh Kazuo Kobayashi et all menunjukkan bahwa pemberian kopi selama 21 hari pada tikus sprague dawley dapat menurunkan kadar trigliserida. ${ }^{19}$

Kopi mengandung kafestol yang bersifat antagonis dengan kafein. Hal ini dibuktikan oleh penelitian De Ross dan Strandhagen bahwa konsumsi kopi tanpa filter yang mengandung kafestol sebanyak $200 \mathrm{ml}$ yang diberikan 5 kali setiap hari dapat meningkatkan kadar trigliserida $0,32 \mathrm{mmol} / \mathrm{L} \cdot{ }^{7,9} \mathrm{Kafestol}$ dapat menghambat proses beta oksidasi sehingga kadar trigliserida dalam darah meningkat. ${ }^{7}$ Pada pemberian kopi robusta filter diduga kafestol pada larutan kopi telah tersaring, sehingga kafestol dalam larutan kopi filter lebih sedikit daripada larutan tanpa filter. ${ }^{10}$ Hal ini menyebabkan fungsi kafein lebih kuat dalam menurunkan kadar trigliserida darah, sehingga penurunan kadar trigliserida dalam darah pada kopi filter lebih banyak daripada penurunan pada kopi tanpa filter. Dilihat dari asupan pakan tikus selama perlakuan diketahui rerata asupan pakan tikus selama perlakuan pada kelompok perlakuan kopi tanpa filter $(15,46 \pm 1,64)$ dan pada kopi filter $(15,22 \pm 1,80)$. Meskipun uji statistik menunjukkan tidak terdapat perbedaan asupan antara kedua kelompok, pada kelompok P2 diketahui mengalami penurunan asupan yang lebih banyak daripada kelompok P1. Hal ini juga mempengaruhi penurunan kadar trigliserida pada kelompok P1 lebih besar dibanding P2. Terjadinya penurunan asupan pakan pada semua kelompok diduga merupakan salah satu faktor terkuat yang mempengaruhi penurunan kadar trigliserida.

Larutan kopi maupun air putih yang diberikan secara per oral pada ketiga kelompok dalam sehari mempunyai volume yang sama, yaitu 10,8 ml. Akan tetapi, pada larutan kopi mempunyai efek diuresis dari kafein yang lebih tinggi. ${ }^{20} \mathrm{Hal}$ ini diduga menyebabkan pengeluaran urin lebih cepat dan lebih banyak pada kelompok yang diberi larutan kopi. Hal ini menyebabkan pengosongan lambung yang lebih cepat sehingga menimbulkan rasa lapar, menyebabkan asupan pakan tikus pada kelompok perlakuan P1 dan P2 lebih tinggi dari pada $\mathrm{P} 0$.

\section{KETERBATASAN PENELITIAN}

Keterbatasan penelitian ini adalah tidak dilakukan uji kandungan kafein dan kafestol dalam bubuk kopi robusta sehingga kadar zat yang mempengaruhi kadar trigliserida dalam pemberian larutan kopi tidak dapat diketahui secara pasti. Penggunaan laboratorium klinik untuk manusia diduga berpengaruh pada ketelitian pengukuran dan hasil penelitian.

\section{SIMPULAN}

Tidak terdapat perbedaan perubahan kadar trigliserida pada pemberian kopi robusta filter dan tanpa filter.

\section{SARAN}

1. Perlu penelitian lebih lanjut mengenai pengaruh pemberian kopi robusta filter dan tanpa filter terhadap kadar trigliserida dengan memperhatikan penggunaan laboratorium klinik maupun laboratorium pemeliharaan hewan coba yang sudah terstandar kualitasnya.

2. Perlu penelitian lebih lanjut mengenai pengaruh pemberian kopi robusta filter dan tanpa filter terhadap kadar trigliserida dengan melakukan uji terhadap kandungan kafestol dan kafein. 


\section{DAFTAR PUSTAKA}

1. Sjamsyuir M. Latar belakang dan patofisiologi hiperlipidemia. Dalam: Rio Rahardjo, editor. Farmakologi. Jakarta: EGC; 2004. hal. 404-405.

2. Anwar TB. Dislipidemia sebagai faktor risiko penyakit jantung koroner. 2004. [serial online]. Diunduh dari : http://Library.usu.ac.id

3. SKRT. Departemen Kesehatan RI Badan Penelitian dan Pengembangan Kesehatan. Jakarta : 2005.

4. Mayes PA. Lipid dengan makna fisiologis yang penting. Dalam Murray RK, Granner DK, Rodwell VW. Biokimia Harper 27th edition. Jakarta: EGC ; 2009.hal:128-139

5. Departemen Perindustrian. Roadmap industri pengolahan kopi. Jakarta. 2009 [serial online] [dikutip pada tanggal 23 maret 2012] Diunduh dari http://agro.kemenprin.go.id/uploads/pdf/ROADM AP-KOPI.pdf

6. Ivan S. Analisis kepuasan dan loyalitas konsumen coffeeshop serta implikasinya terhadap strategi pemasaran. Departemen Agrobisnism Fakultas Ekonomi dan Manajemen. Bandung : Institut Pertanian Bogor; 2009.

7. De Ross B, Muriel JC, Stalenhoef A, Bedford D, Demacker PNM, at al. The coffee diterpene cafestol increase plasma triacylglycerol by increasing the production rate of large VLDL apolipoprotein $\mathrm{B}$ in healthy normolipidemic subject. J. Nutr. 2001; 45-51.

8. Adebayo JO, Akinyika AO, Odewole GA, Okwusidi JI. Effect of caffeine on the risk of coronary heart disease a re-evaluation. Indian J.Clin.Nutr. Nigeria : 2007; 29-31.

9. Strandhagen, Thelle DS. Filtered coffee raises serum cholesterol. Europan J.Clin.Nutr. Sweden : Sahlgrenska University Hospital : 2003; 134-42.

10. Dusseldorp M, Katan MB, Vilet T, Demacker PN, Stalenhoef AF. Cholesterol-raising factor from boiled coffee does not pass a paperfilter. Arterioscler Thromb 1991;11:586-93

11. Istiadi H, Sunarsih ES. Pengaruh jus lidah buaya terhadap kadar kolesterol tikus hiperlipidemia. Media Medika Muda : Medical Faculty of Diponegoro University. Semarang :2010

12. Valtek Diagnostic. Total cholesterol (CHODPAP), HDL cholesterol, LDL cholesterol, trigliserid GPO-PAP. Diunduh di: http;//www.valtekdiagnostics.com

13. Dahlan MS. Statistik untuk kedokteran dan kesehatan. Ed3. Jakarta: Salemba Medica; 2001.hal.3-4

14. Demirtas C, Hussein A. Effect of caffeine on oxidant-antioxidant mechanisms in the rat liver. J.Nutr. 2010; 14-15.

15. Mayes PA. Sintesis, pengangkutan dan penyimpanan lipid. Dalam: Murray RK, Granner
DK, Mayes PA, Rodwell VW,editor. Biokimia harper. 27th ed. Jakarta: EGC; 2009.hal.225-239.

16. Shugiura $C$, Nishimatsu S, Moriyama $T$, et al. Cathecins and caffeine inhibit fat accumulations in mice through the improvement of heatic lipid metabolism. Research Article. 2012(2012): 1-8

17. El-Ghany A, M.A, Rash, et al. Hypolipidemic effect of caffeine beverages in fatty liver injury rats. J.Nutr. 2012; 8(3): 1502-8

18. Schoppen S. et al. A sodium-rich carbonated mineral water reduces cardiovaskular risk. J.Nutr. 2004;134(5): 1058-60.

19. Kobayashi K, Mogi A, Matsumoto Y, et al. Effect of caffeine on the body fat and lipid metabolism of rats fed on a high-fat diet. J.Biochem. 2005;69(11): 2219-2222.

20. Maughan RJ, Griffin J. Caffeine ingestion and fluid balance. Research Article. 2003;16(6): 411418 . 